\title{
EUROPEAN INFLUENCE OF DUTCH AND FLEMISH ART CULTURAL MOBILITY
}

\author{
LUDO BEHEYDT
}

\begin{abstract}
The future for European interdisciplinary culture studies lies in the recognition of the dynamics in European culture. If European citizens are to identify with Europe, a familiar European culture has to be offered to them. That familiarity will not be found in a national history or national culture studied in isolation, nor will it be found in European history or culture. Europe does not have a common cultural identity, a shared web of significance. A way out of this dilemma is conceiving European culture as the result of a continuous cross-pollination. Such a view is presented here in an exemplary approach to art, looking at Flemish and Dutch art as a meeting point of cultural influences.
\end{abstract}

Key words: European culture; cultural mobility; cultural identity; Flemish and Dutch art

\section{Introduction}

In the European context a new Cultural narrative for Europe is urgently needed. If we want European citizens to identify with Europe, recognition of the dynamics in European culture is an absolute necessity. Neither the narrow national look at art, nor the cosmopolitan generalizing view is an adequate approach. It is an obsolete nationalistic stalemate to look at the art of the Low Countries as an isolated essentialist cultural production. The current rigid compartmentalization of cultures as stable, timeless and recognizable is an academic myth. But it is as simplistic and mythical to look at European art as an integrated unitary artistic expression. There is no stable, timeless and recognizable European art either. A way out of these overly narrow visions is conceiving European art as the result of a continuous cross-pollination, a fascinating encounter of legacies, in which cultural identities find their way in diversifying artistic influences.

The challenge for a new cultural narrative for Europe, therefore, will be that of striking the right balance between recognition of today's cultural super-diversity and the respect for the cultural identity of the heritage of local cultures. To adequately address this paradox Stephen Greenblatt (Greenblatt, 2010, 3-4) proposed to fully acknowledge 
the cultural mobility of each and every culture, that is, "the vitally important dialectic of cultural persistence and change" $(2010,2)$, which he considers as the ceaseless process of 'cultural mobility'. In terms of a European cultural policy development, taking account of cultural mobility would imply recognizing and acknowledging the constraints of cultural continuity that define cultural identity, while at the same time revealing the dynamics in cultural identity and the process of hybridization caused by diversified encounters between cultures (Burke, 2009).

The basic dialectic between rootedness and change, between fixity and dynamics, which according to Greenblatt forms the essence of universal cultural mobility, challenges both the assumption of cultural stability and the belief in total cultural relativism. In an effort to reorient European cultural studies in accordance with recognition of cultural mobility, we approvingly refer to Greenblatt's outline of a five-point set of basic principles to guide our new look at Netherlandish art.

These principles are (Greenblatt 2010: 250-253):

"First, mobility must be taken in a highly literal sense. [...]

Second, mobility studies should shed light on hidden as well as conspicuous movements of peoples, images, texts and ideas. [...]

Third, mobility studies should identify and analyze the 'contact zones' where cultural goods are exchanged. [...]

Fourth, mobility studies should account in new ways for the tension between individual agency and structural constraint. [...]

Fifth, mobility studies should analyze the sensation of rootedness."

Operating with this set of principles as guidelines for a new approach to European culture will lead to a totally new look at national art, which is more in line with today's super-diverse European societies and, at the same time, offers a better access to the specific patterns of meaning that identify European cultural communities. It will be shown in an exemplary case of the development of 'Netherlandish art' (in the early modern period, 1450-1650) for a European audience, that applying these principles will have far reaching consequences for the new artistic narrative about art in Europe.

\section{Mobility in the literal sense}

A systematic elaboration for Netherlandish art of the five principles of the Mobility Studies Manifesto (2010) advanced by Greenblatt, leads us, first of all, to the literal sense of mobility. Only by taking account of the actual patterns of mobility of artists, will it be possible to explain the metaphorical movement of influences, from superficial to fundamental, from local to global, from resistance to acceptation.

Mobility of Netherlandish artists was already common from the middle of the fifteenth century on. The famous Flemish primitive Rogier van der Weyden (1399-1464) was the first artist to have undertaken the journey to Italy. He went to Rome in the Jubilee Year 1450 where his emotional work was admired by the local painters and he immediately greatly influenced Italian painting. Hints of interest among Italian painters are evident even before this visit: the use of oil by Piero della Francesca about 1448-1450 during his 
stay at the court of Ferrara and by the Ferrarese painter Cosmè Tura in the late 1450s suggests study of the technique of Rogier van der Weyden, whose famous triptych of the Deposition (Figure 1) was present at the humanist court of Leonello d'Este as we know from its eulogistic description by the antiquary Ciriaco d'Ancona in 1449. But certainly in Florence painting alla fiamminga became trendy and an emulation of Netherlandish visual qualities of Jan Van Eyck's and Rogier Van der Weyden's work, such as the eye for minute detail and the technical virtuosity, changed the way of Florentine painting thoroughly (Nuttall 2004).

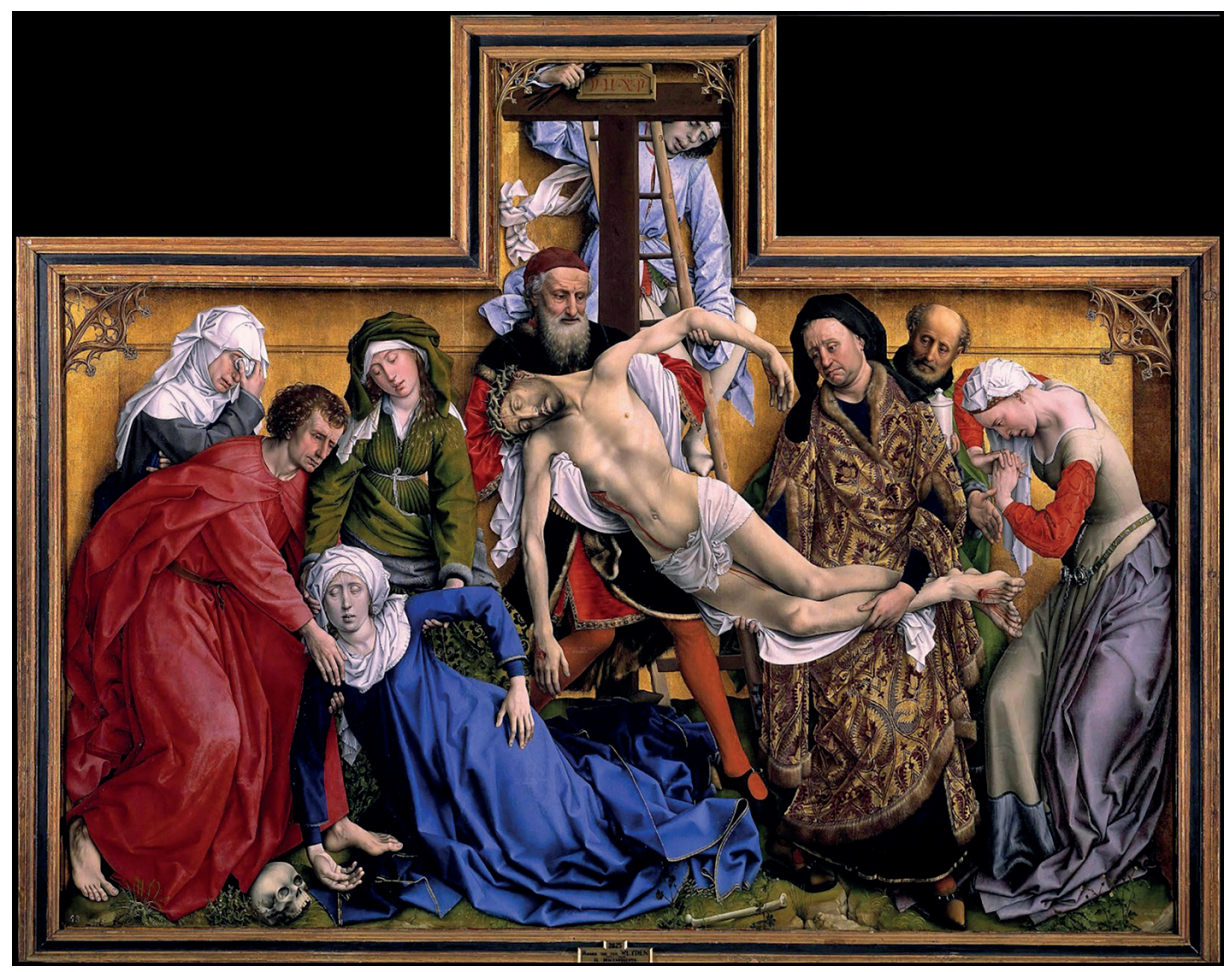

Figure 1. Rogier van der Weyden - The Deposition (1435) - Museo del Prado, Madrid

Not only Florentine painting though! Van der Weyden's and Van Eyck's fame were so overwhelming in Italy that some Italian masters started to paint in the Netherlandish fashion. The Sicilian Antonello da Messina is probably the most typical example. No other Italian artist of the $15^{\text {th }}$ century responded in such a direct fashion to the Flemish primitives. His work is so overtly Flemish that the sixteenth century connoisseur Marcantonio Michiel attributed some of his works to Flemish primitives. The meticulously descriptive realism and the strong coloristic character of his portraits, for instance, convincingly prove direct Netherlandish influence.

From the $15^{\text {th }}$ century on, journeys to Italy became very popular among Netherlandish artists, who often finished their formation by a trip to Rome, Florence, Venice, ... to get personally acquainted with the great Italian art of the Renaissance. Of course, such journeys also highly influenced the Northern painters. Thus, with Van der Weyden we notice 
in a work like The Entombment of Christ a remarkable influence of the Italian elegance he had discovered in the work of Fra Beato Angelico, but which does, nevertheless, never overwhelm his genuine Netherlandish characteristics such as the expressive realism of the faces and the asymmetry in the composition (Hoogewerff 1947). On the other hand, the presence of Van der Weyden in Italy has incited the duchess of Milano, Bianca Maria Visconti, in 1463, to send the young painter Zanetto Bugatto from Milan to Van der Weyden's studio in Brussels for three years to get him acquainted with the Flemish technique of oil painting (Kemperdick 1999: 136). As, however, Van der Weyden died in 1464 Bugatto spent the next two years in the studio of Hans Memling by whom he got so thoroughly influenced in his portraiture painting that some art historians still claim that his portrait of Lodovico Sforza was painted by Memling (Figure 2). His Flemish influenced portraits and landscape backgrounds reflect, indeed, the blend of Netherlandish and Italian styles that interested his Milanese patron. Thus, two-way mobility has caused mutual influence, which continued all through the Renaissance and was already acknowledged by Carel van Mander in his 'Book of Painters' (Schilder-Boeck) as early as 1604, when he wrote that Italy sent its painters to Flanders "so as to suckle at new breasts in Flanders", but at the same time recognized that the Dutch painter Jan Schoorel "brought from Italy insight in the best way of painting".

The assimilation of Italian influences by some Netherlandish artists in the early modern times became so strong that they got designated as 'Italianists' or 'Romanists', names which originally had a disapproving connotation (Dacos 1995: 14). Admittedly, Italian mannerism and 'Romanism' had a great impact on Netherlandish painting of the $16^{\text {th }}$ century. Many painters from the Low Countries did their 'Grand Tour' in Italy and

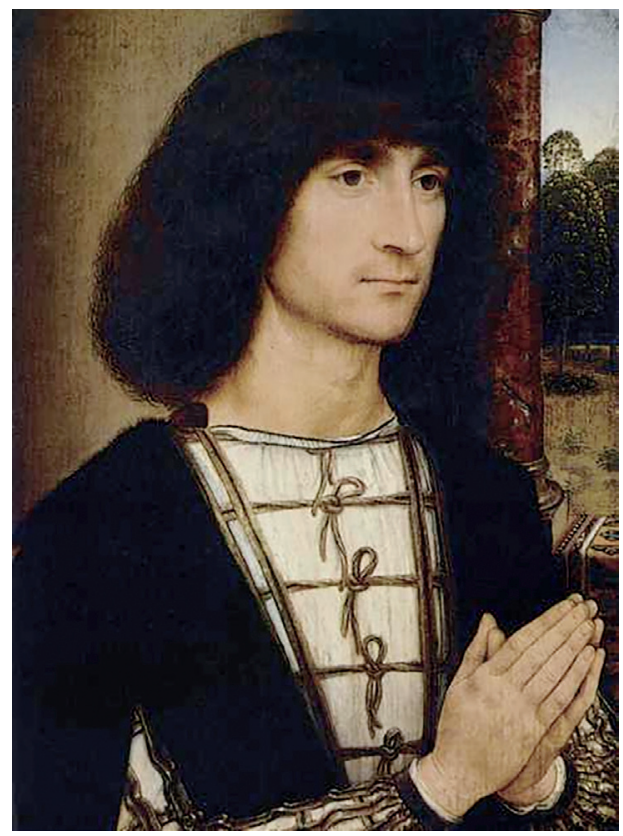

Figure 2. Zanetto Bugatto - Portrait of Lodovico Sforza 


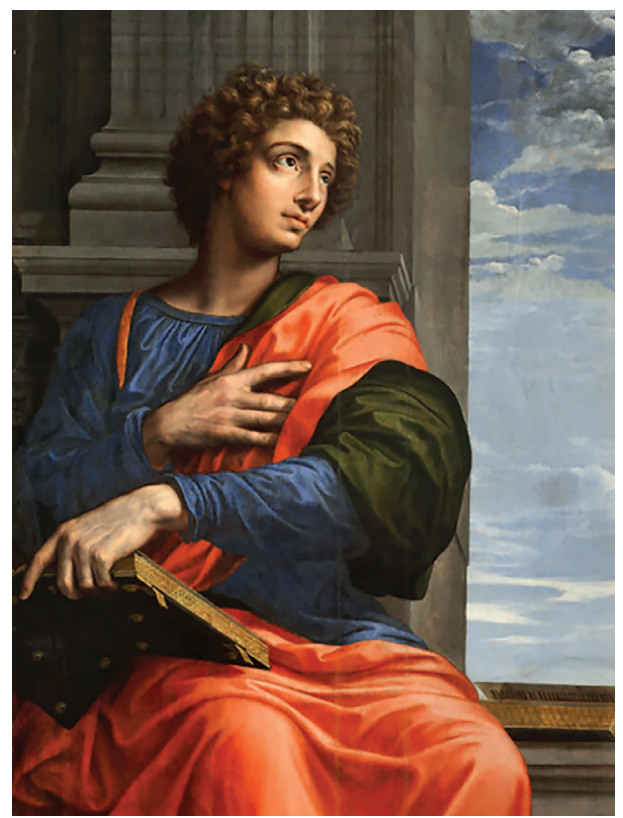

Figure 3. Michiel Coxcie - St. Luke Altarpiece (detail) - National Gallery Prague

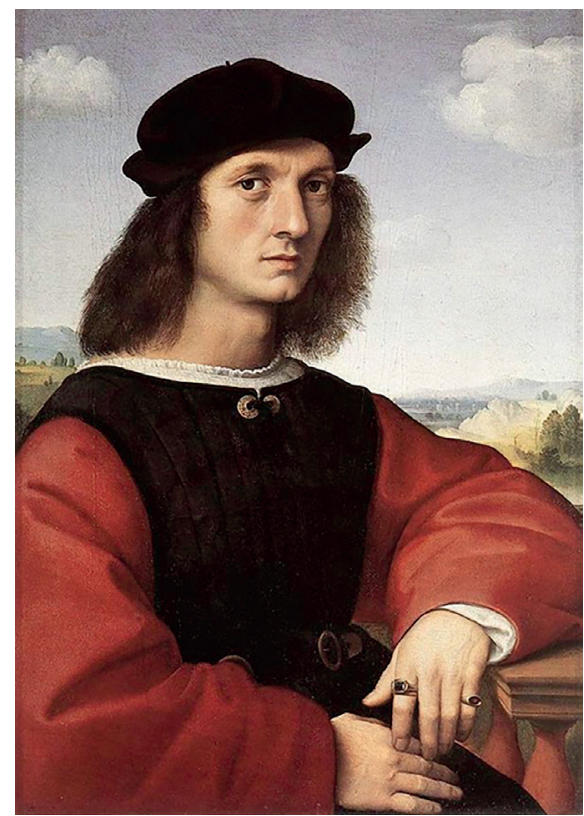

Raphael - Portrait of Agnolo Doni - Pallazo Piti, Florence

familiarized themselves with the innovations of the Italian Renaissance. The groups of Fiamminghi a Roma, young artists that went to Rome to finish their education as painters, stood in sheer admiration before Raphael's Stanze del vaticano and Michelangelo's Vaults in the Sistine Chapel. Raphael had become the example par excellence of perfect universal harmony and Michelangelo had become the ideal of expressive human beauty. So, Netherlandish painters came to Rome to study this new art and wanted to become the 'Flemish Raphael', like Michel Coxcie, or the 'Flemish Michelangelo', like Frans Floris Devriendt. Michiel Coxcie (1499-1592) was one of the most influential painters in the sixteenth-century Netherlands. If he was eventually dubbed the 'Flemish Raphael', it just goes to show how highly rated he was by his contemporaries. Already during his lifetime he was compared to the great Italian renaissance artist Raphael and some even saw him as his equal. And as you may notice in the comparison of one of his works with a portrait by Raphael he was clearly inspired by the clear and harmonious design of Raphael's classical elegance (Figure 3).

The Antwerp painter Frans Floris Devriendt, in turn, was more attracted by the strong expression of human beauty in great compositions with perfectly designed human bodies as we know them from Michelangelo's ceiling of the Sistine Chapel. He followed Vasari's advice to "strive to imitate Michelangelo in all things". Still, although Frans Floris knew about anatomy, perspective and disegno he clearly lacked Michelangelo's mastery to create convincing perfect human forms and to design boldly simple conceptions of scenes. Even if his Fall of the Rebel Angels (1554) (Figure 4) imposes by its technical virtuosity, it is disenchanting by a lack of genius. The Mannerist contorted bodies are never convincing in the overall disegno. 


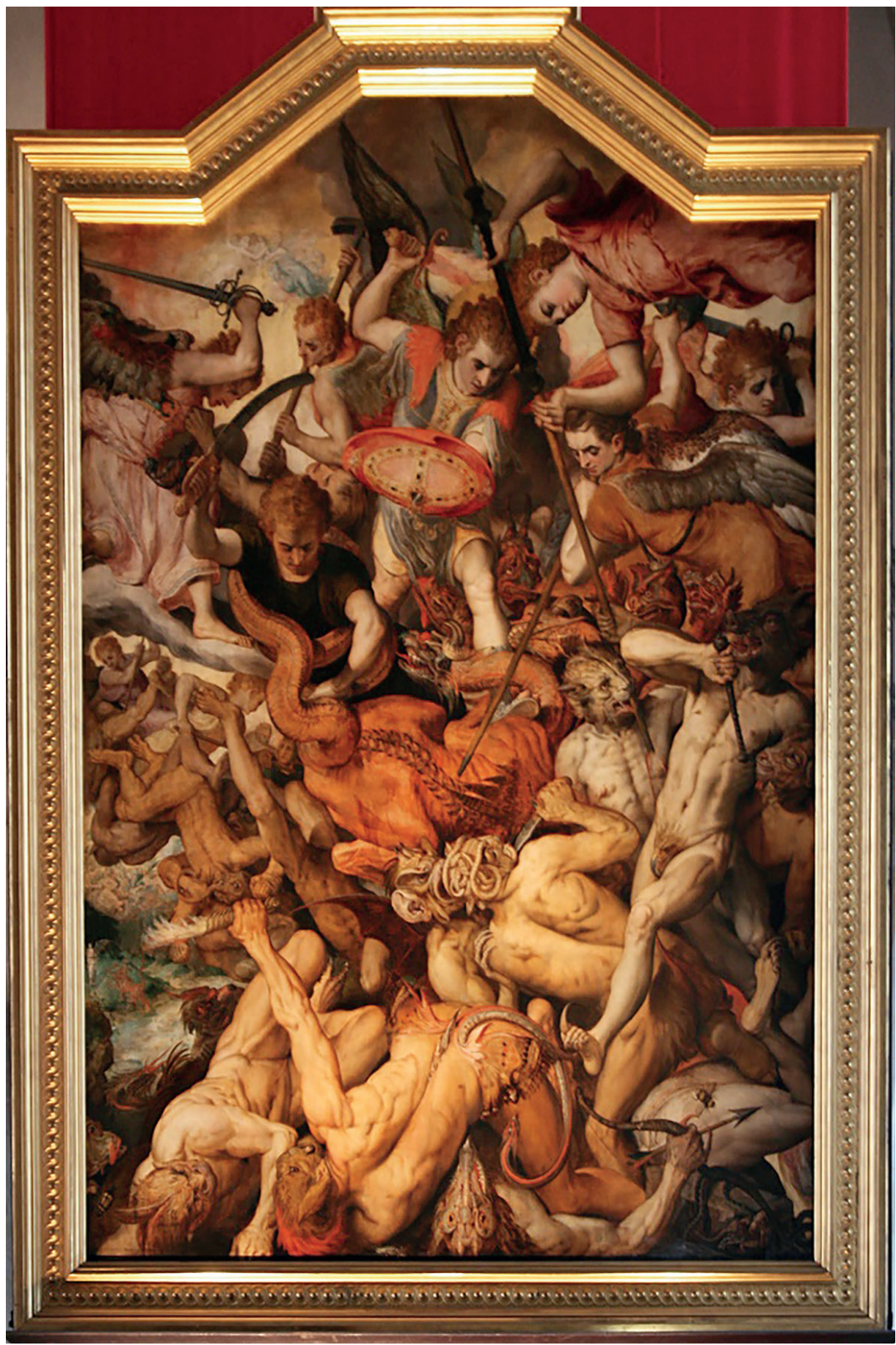

Figure 4. Frans Floris Devriendt - Fall of the Rebel Angels (1554) - Royal Museum of Fine Arts, Antwerp 


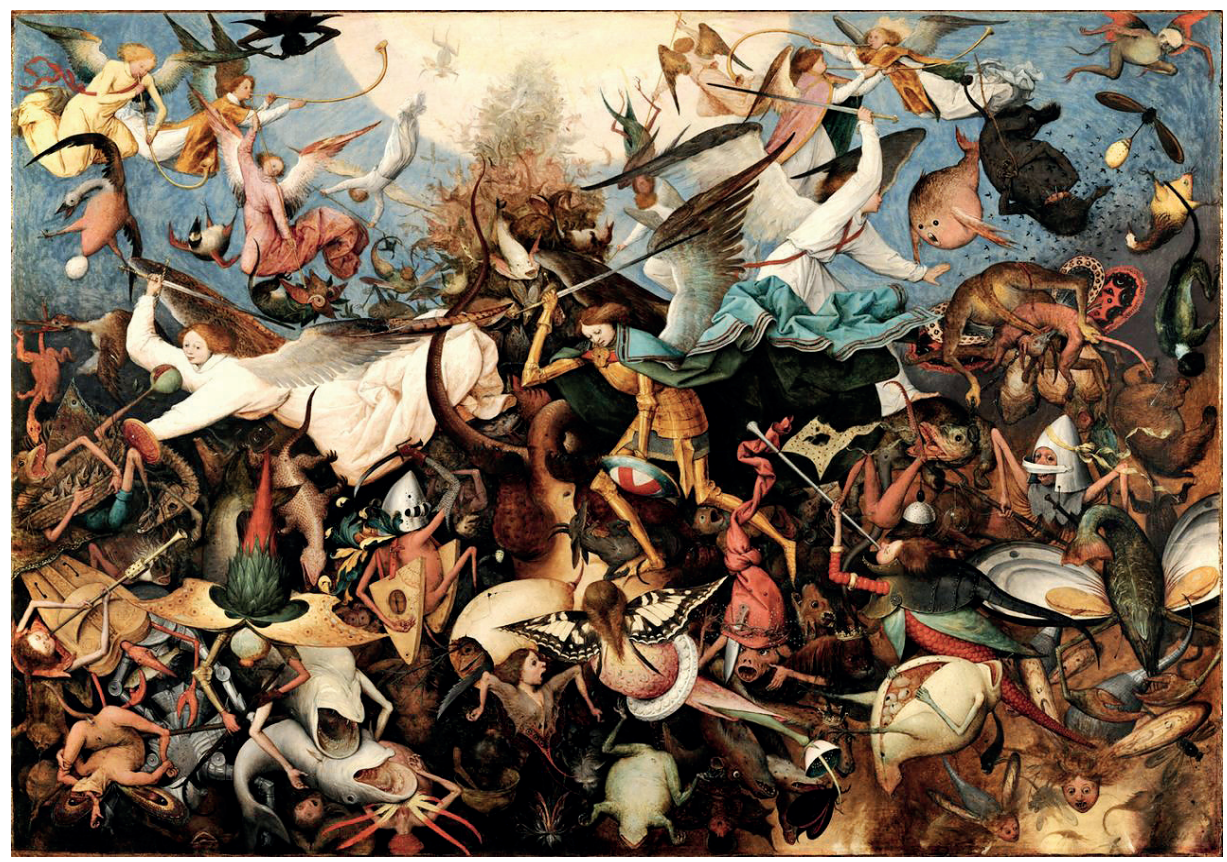

Figure 5. Pieter Bruegel the Elder - The fall of the Rebel Angels (1562) - Royal Museums of Fine Arts of Belgium, Brussels

No lack of genius on the other hand in the work of Pieter Bruegel the Elder who also made his 'Journey to Italy', but who did not want to impress by imitation of the Italians. On the contrary. If we consider his elaboration of the same theme of The Fall of the Rebel Angels (1562) (Figure 5), we are enchanted by the straightforward Flemish gift for fantastic and visionary art. In the great grotesque chaos a circle of light is coming down to the darkness of hell presenting us with the demonic atrocity of damnation. The appalling menagerie of hybrid monsters is chaotically at war with the Saint Michael.

Was not Bruegel influenced by his 'Grand Tour' through Italy then? He certainly was, as he brought us great landscape drawings and engravings from his journey. But he was no imitator. He is the perfect example of cultural mobility, as he skillfully integrated what he had seen in Italy into his genuinely Flemish work. In The Fall of Icarus (Figure 6), for instance, he created a world landscape that presents a foreground with a truly Flemish view, a Brabantic hill slope on which a farmer is ploughing, continues ploughing, despite the great mythological drama that is happening, the Fall of Icarus, a drama that takes place unnoticed. The great mythological event is reduced here to a tiny leg disappearing in the water. The painting reminds us of a Flemish proverb (of the sort imaged in other works by Bruegel): "And the farmer continued to plough..." (En de boer ... hij ploegde voort) pointing out the futility of the great mythological drama's in comparison to the never ending seasonal work of the ordinary man. Genuinely Flemish in spirit and yet touched by Italian influence, for in the depth of the landscape we discover a wonderful Italian bay of Messina. Thus, Bruegel has created a new type of landscape which has deeply influenced European landscape painting later on. 


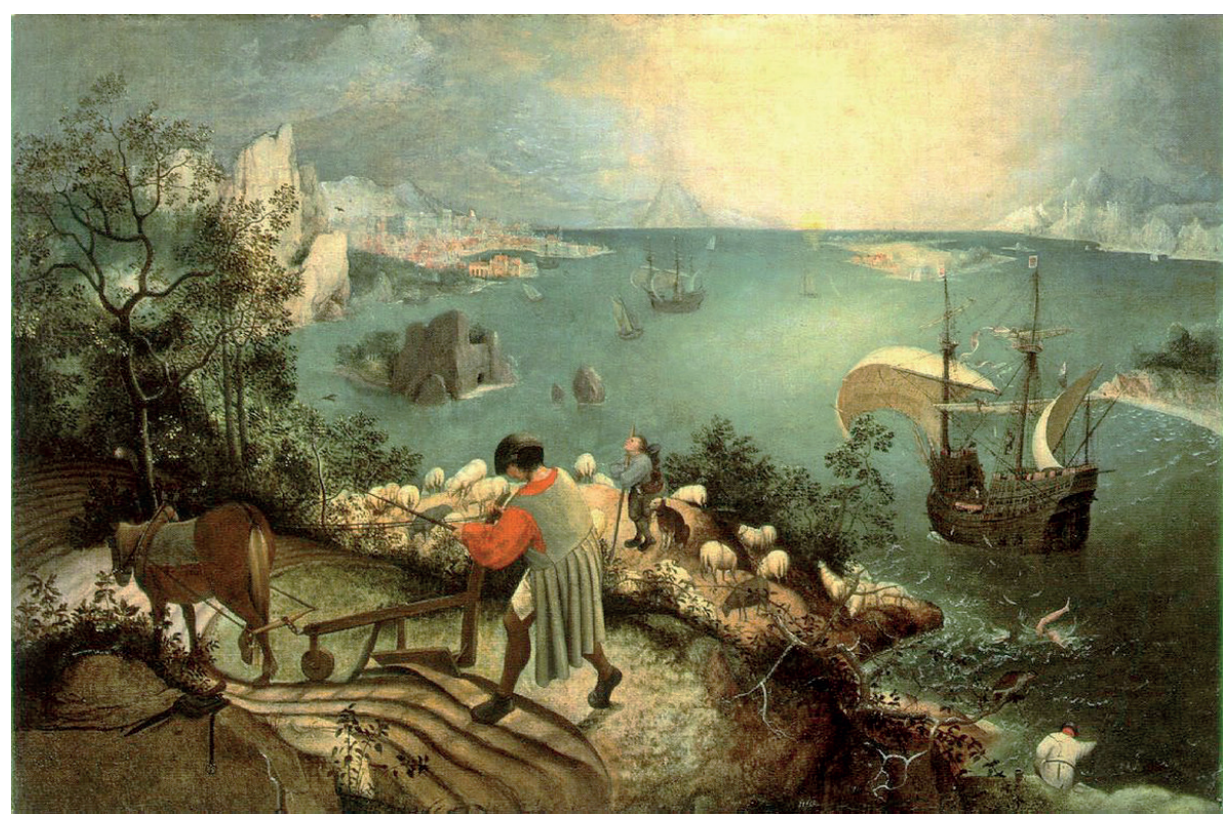

Figure 6. Pieter Bruegel the Elder - Landscape with the Fall of Icarus (1558) - Royal Museum of Fine Arts of Belgium, Brussels

Bruegel was the genial exception and in that he differed from many of his contemporaries who were infatuated with the luster of Rome. A typical example is Jan Gossaert (1478-1532), who is often considered as the first Renaissance artist or 'Romanist' from the Low Countries and who went to Italy in 1508 as a member of the entourage of Prince Philip of Burgundy. Gossaert was fascinated by the great Roman sculptures he discovered in the Courtyard of the Sassi family and in the Palazzo dei Conservatore in Rome (Ainsworth 2010) and introduced an innovative Italian sculptural approach in Netherlandish painting, but he remained loyal to the extraordinary meticulous style inherited from the Van Eyck tradition. In Saint Luke painting the Virgin (ca. 1520) (Figure 7) (Prague, Narodni Museum), for instance, he faithfully follows the Flemish verism and the almost gothic plasticity of Van der Weyden, lending the virgin Mary a sculptural volume and a warm sensuality, but he situates this typical Flemish scene in an Italianate spatial structure with striking effects of perspective foreshortening. The integration of Italian innovations in the Flemish tradition certainly had an impact on the cultural identity of Netherlandish art, but did not wash it away. Despite the obvious Italian influence, Jan Gossaert remained recognizably tied to the Netherlandish tradition (Beheydt 2002).

In general, the mobility of the artists did not annihilate their recognizable cultural identity, it only contributed to their cultural mobility. Even if Netherlandish artists got employed in Italy, they developed their identity in artistic interaction with their new environment and they influenced the receiving Italian culture. Thus, when Federico da Montefeltro received the Flemish master Justus of Ghent ('Giusto da Guanto') in 1473 at the court of Urbino, the Fleming did not 'Italianize' completely. Paula Nuttall elucidated his process of cultural mobility aptly and concisely as follows: 


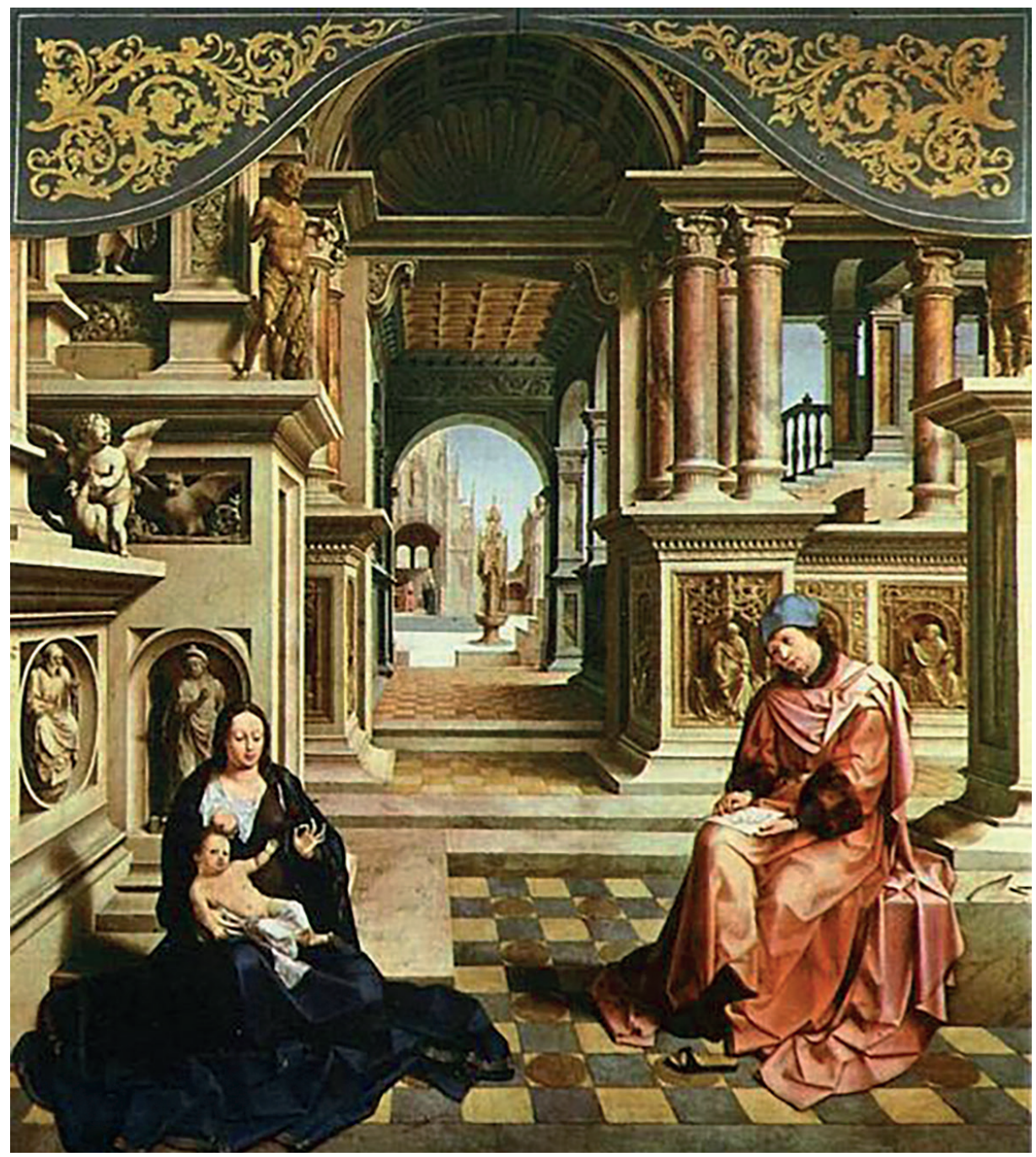

Figure 7. Jan Gossaert - Saint Luke painting the Virgin - National Museum, Prague

"The experience of working in the rarefied artistic ambience of Urbino itself had a cataclytic effect on Justus; his style underwent a rapid transformation, acquiring an increasing Italianate monumentality, a grace, an understanding of perspective, and an assimilation of renaissance architectural forms, without any loss of native virtuosity or verisimilitude." (Nuttall 2004: 4)

In the context of a European look at Netherlandish art, it is fascinating to study this process of continuous cross-pollination due to actual mobility of artists. A typical example of outspoken cultural mobility with mutual influence on the native culture and on the foreign culture is the famous Utrecht School with the leading artist Gerard (or Gerrit) van Honthorst, in Italy also named Gherardo delle Notti, who within a traditional Nether- 


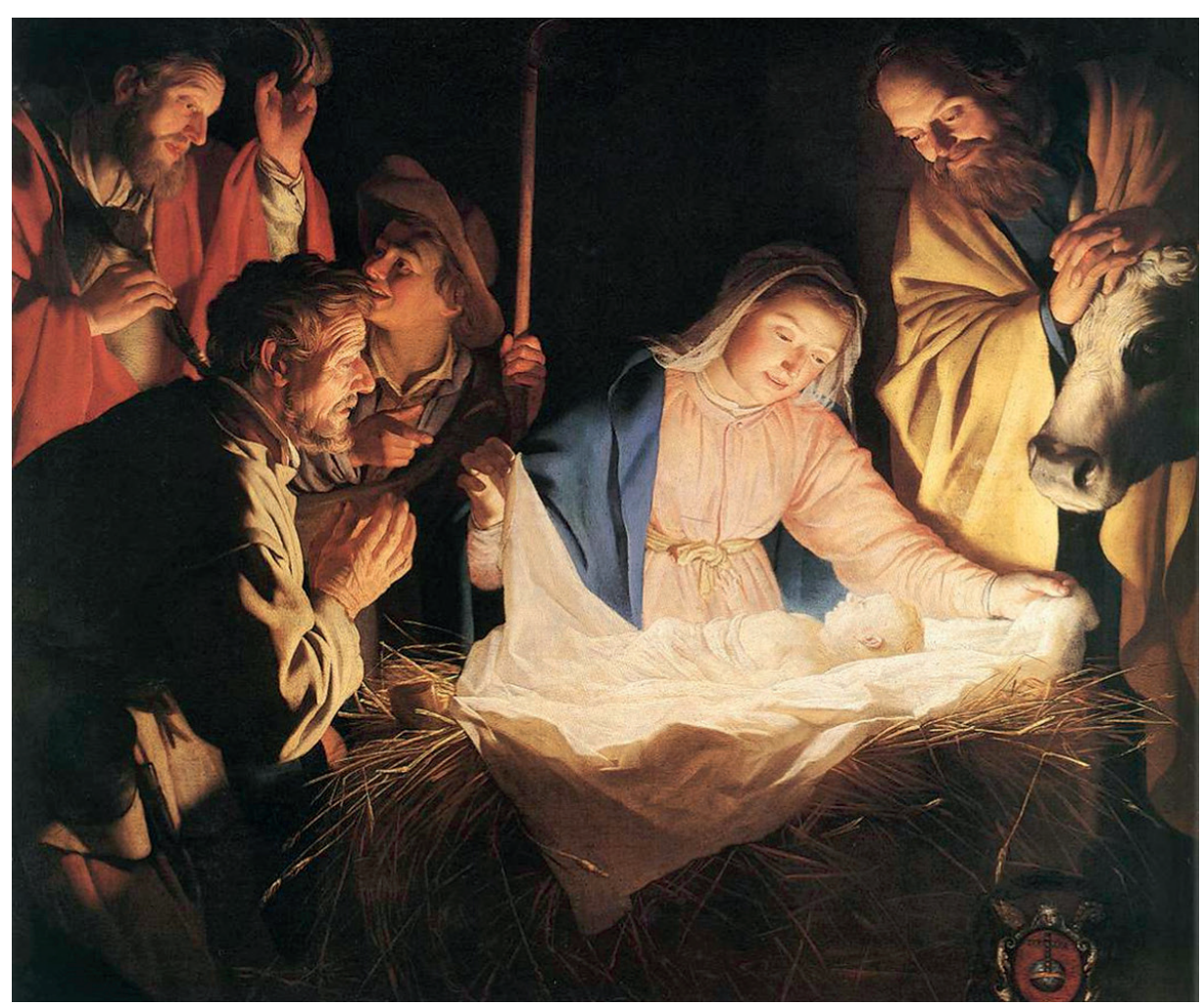

Figure 8. Gerrit van Honthorst - The adoration of the Shepherds (1622) Wallraf-Richartz Museum, Cologne

landish iconography, introduced a composition technique totally inspired by Caravaggio (Judson, 1959). The Adoration of the Shepherds (Figure 8) signed by Honthorst in 1622 at a glorious moment in his career, is an iconic example of the harmonic reconciliation of the stark chiaroscuro's of Caravaggio on the one hand, and the typical Dutch gift for subtle effects of light on the other hand, not unlike those of Johannes Vermeer.

Honthorst enjoyed a stay in Italy where he got acquainted with the work of Caravaggio and subscribed almost immediately to Caravaggio's revolution. His earliest work in Italy still reveals all the raw strength of a young northern artist overwhelmed by Caravaggio's naturalism and his strong clair-obscur. In 1620 Honthorst returned from Italy to his home town Utrecht as a celebrated painter, and introduced an artistic innovation that was immediately successfully taken over by an Utrecht group of Netherlandish painters: the Caravaggesque nocturne with life-size half-length figures.

As you may notice in the Adoration of the Shepherds this Caravaggesque chiaroscuro was eminently suited to directly involve the spectator with the miracle of the Holy Night, as the spectator gets taken up in this mysterious circle of light. The figures also share Carvaggio's realism. The child is the sole light source. His radiance illuminates the realistic faces of Mary, Joseph and the shepherds, evoking intensive emotions: the quiet bliss of the parents, the joyful awe and humble reverence of the shepherds. This 


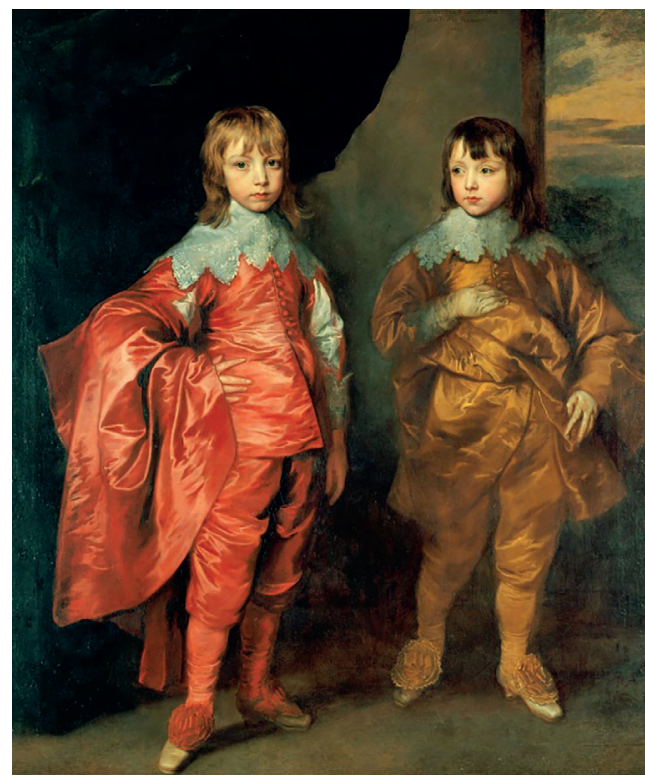

Figure 9. Anton van Dyck - Portrait of George Villiers (1635) - Huntington Library

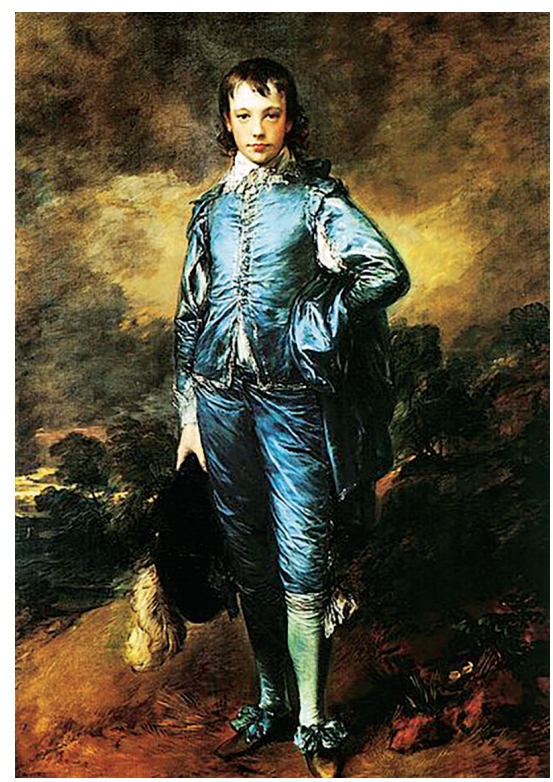

Thomas Gainsborough - Blue boy (ca. 1770) Royal Collection - Windsor Castle

painting harmoniously fuses the Northern sensibility for subtle light shades with the caravaggesque tendency to stark chiaroscuro. The artificially lit scenes do not share the caravagessque harshness but show a typical Dutch intimacy. Such stark naturalistic chiaroscuro light scenes soon influenced Netherlandish painting and contributed the dissemination of Caravaggio's style in Holland through the Utrecht School, consisting principally of Honthorst himself, Dirck van Baburen (c. 1590-1624), Hendrik Terbrugghen (1588-1629) and Jan van Bijlert (1597-1671). They introduced the dramatic chiaroscuro and established new stylistic and iconographic models that were soon imitated by other artists and contributed to Netherlandish cultural mobility.

Of the Flemish artists of the early modern period that due to their factual mobility exerted the greatest influence on European art, Pieter Paul Rubens and Anton van Dyck are certainly the most important. Both extensively moved from court to court in Europe and developed their artistic identity in continuous interaction with their respective artistic environments, yet leaving an enduring mark on the receiving cultural identity thus contributing to the cultural mobility.

I only take the example of Anton Van Dyck, who was a restless traveler and worked in Italy, the Spanish and the republican Netherlands, to finally arrive in England as the court painter of Charles I. Although Van Dyck spent only seven years in England, he caused a revolution in British portrait painting which was to find deep resonance well into the $20^{\text {th }}$ century. Especially in the $18^{\text {th }}$ century his elegant style and several of the new genres (children, 'friendship' pairs) he introduced were followed by the most successful portrait painters, such as William Hogarth (1732-1750), Thomas Gainsborough (1727-1788), Joshua Reynolds (1723-1792) and Thomas Lawrence (1769-1830). Gainsborough's famous 'Blue boy' (ca. 1770) is even a direct homage to Van Dyck and clearly 
reminds us of Van Dyck's George Villiers, $2^{\text {nd }}$ Duke of Buckingham (1635) in pose and dress (Figure 9), just as Joshua Reynolds' portrait of George Seymour Conway (1771) shows us the young lord in a typical Van Dyck silk costume. Undeniably, Van Dyck's artful fiction, graceful postures, casual glamour, cultivated ease and his shimmering drapery marked British portraiture for centuries and contributed to what later has been called 'the English look', the negligent charm of the English upper class. As Martin Gayford $\left(2009,21^{\text {st }}\right.$ January, The Telegraph) so aptly remarked: "With a change of outfit, Van Dyck's Dorothy, Viscountess Andover and her Sister Elizabeth, Lady Thimbleby (c1637) would be perfectly at home in the pages of [today's quintessential glossy British magazine] Country Life".

\section{Conspicuous movements of texts, images and ideas}

It is not only the actual mobility of artists that causes cultural mobility, the movements of works, images and ideas certainly contributes to the dynamic character of cultural identity as well. Paula Nuttall (2004), for instance, has convincingly shown, how during the quattrocento Italians came into contact with Netherlandish pictorial models through drawings, model books, prints, and certain Netherlandish paintings that were displayed in Florence in accessible locations. She also subtly analyzed the modes of

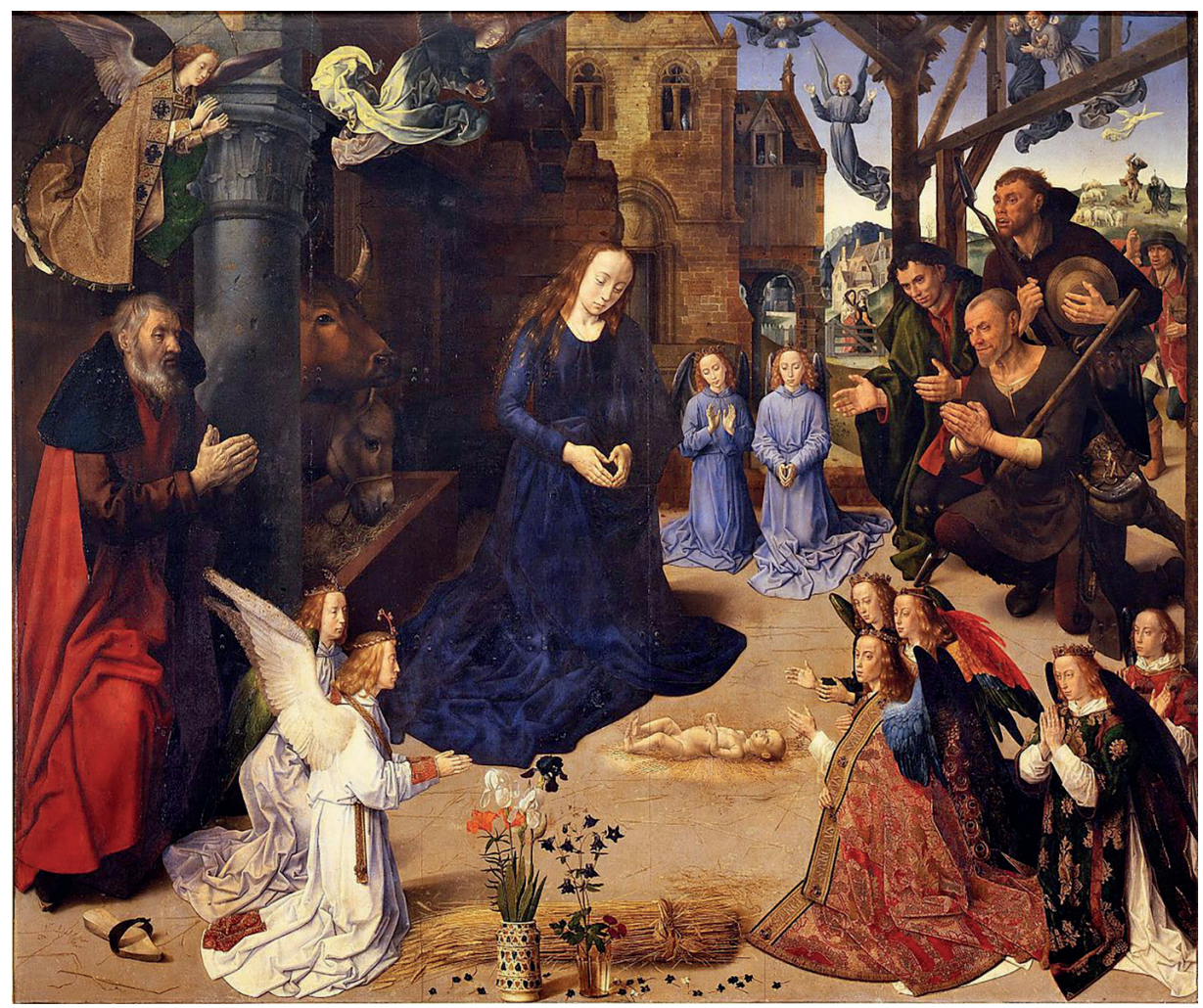

Figure 10. Hugo van der Goes - Portinari triptych (1475) - Uffizzi, Florence 
response of Italian artists - ranging from obvious imitation, to appropriation, selective borrowing and creative personal interpretation - thus revealing the dialectic between rootedness and mobility and the accompanying hybridization.

The influence of the Flemish primitives was not only exerted in Italy. Already in the fifteenth century work by Jan van Eyck and Rogier van der Weyden also deeply influenced painting in Central Europe. German painters, for instance, came into contact with the work of Rogier van der Weyden through the display of the famous Columba triptych with The Adoration of the Magi (ca. 1455) in the Columba church in Cologne. And from the end of the $15^{\text {th }}$ century on, due to the growing influence of successful prints as intermediaries, German art was greatly inspired by popular motives and image compositions of the Flemish primitives.

Display of important works in accessible locations, such as churches, has proven enormously important for the influence of Flemish art. Hugo van der Goes' Portinari Triptych (Figure 10), for instance, which was ordered in Bruges by the Florentine expat Medici banker Tommaso Portinari and sent to Florence in 1475 for the Arcispedale di Santa Maria Nuova, caused a shock among Italian painters. This impressive Adoration must have seemed very uncanny to the Italian painters, because the perspective is so wrong according to Italian Renaissance principles, as the groups of people are placed in the composition each with their own perspective. In line with the Burgundian religious view of art, the relation in height between the groups is not dictated by geometric perspective, but by religious perspective: the most important groups have the most outspoken spatial importance.

Very strikingly Flemish in this painting was, moreover, the introduction of the common people. The unshaven shepherds are terribly naturalistically-depicted country people. These all too realistic rustic characters have impressed and seduced the Italian court painters.

So we can notice how, when Domenico Ghirlandaio painted his Adoration in 1485 for the Cappella Sassetti in Santa Trinità in Florence (Figure 11), he masterfully combined the classical spirit so dear to the Italians, with the newly discovered rude realism of the Netherlandish master. The shepherds in his Adoration are clearly modelled after the example of Hugo van der Goes' shepherds. Yet, despite its Flemish influence, Ghirlandaio's Adoration has not become a Flemish painting.

Apart from the Netherlandish influence in Europe, there is of course the foreign influence on Netherlandish art which is an equally important contribution in the cultural mobility. Here too, it will certainly be necessary to begin by looking at the conspicuous influence of incoming foreign images such as the Italian Renaissance engravings and prints. The reproduction in print of famous paintings made it possible for artists in the Low Countries to come into contact with foreign art. The boom of print production during the Renaissance has had a tremendous influence on Netherlandish painting (Landau \& Parshall 1994). Italian prints based on the work of Raphael or Michelangelo familiarized many Netherlandish painters with Italian art, even if they themselves had not made the customary trip to Italy.

Thus, the Italian engraver Marcantonio Raimondi, who produced engravings of the works of Raphael that were massively spread in the Low Countries (Figure 17), caused the Dutch painter Lucas van Leyden to introduce nudes into his works and to dramatize 


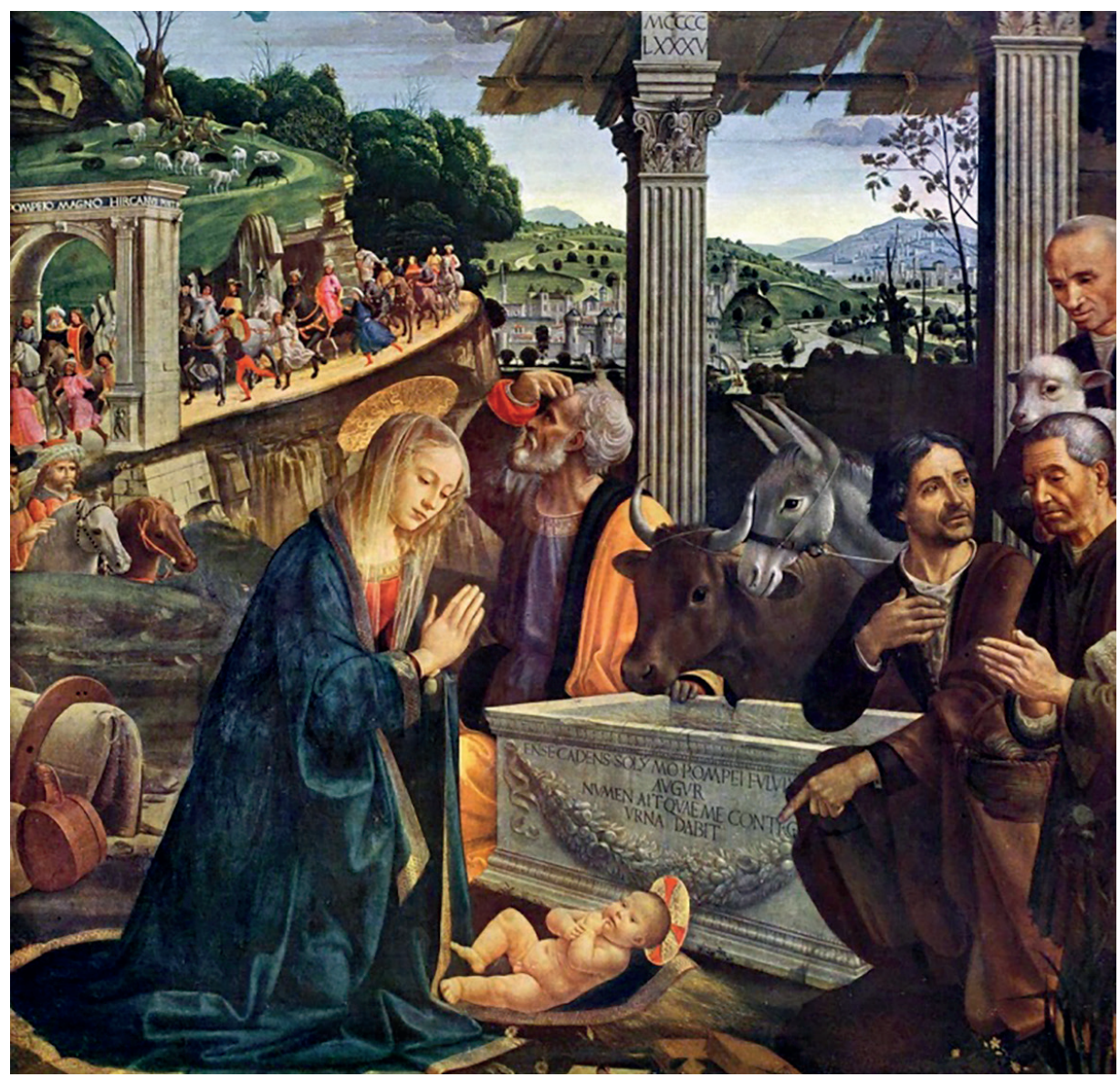

Figure 11. Domenico Ghirlandaio - Adoration of the Shepherds (1485) Sassetti Chapel panel, altarpiece, Florence

action in his paintings in the Italian way. But, again, the influence was reciprocal. Marcantonio Raimondi, in turn, copied part of a landscape from a print by Van Leyden.

On top of such overt borrowings, there were also more disguised forms of borrowing and hybridization, inspired by deliberate hiding and insubordination. A notorious example is Pieter Bruegel the elder, who took over familiar catholic themes such as The Census at Bethlehem or The Preaching of St. John the Baptist, that were acceptable traditional subjects under the catholic Spanish reign, but he incorporated disguised insubordinate and subversive signs of rebellious mobility in reaction to Spain's religious regime of repression (Beheydt 2002: 97-99). He thus turned the innocent Biblical scene of the Preaching of St. John the Baptist (1566) into a hardly disguised subversive 'Hagenpreek' (hedges sermon), the type of clandestine sermon held by the Protestant reformers of that time (Figure 12).

Conversely, in the seventeenth century, when under the Protestant Dutch Republic Catholic imagery became suspicious, Catholic themes were nevertheless appropriated and accommodated by painters, again causing cultural hybridization. Thus, for instance, 


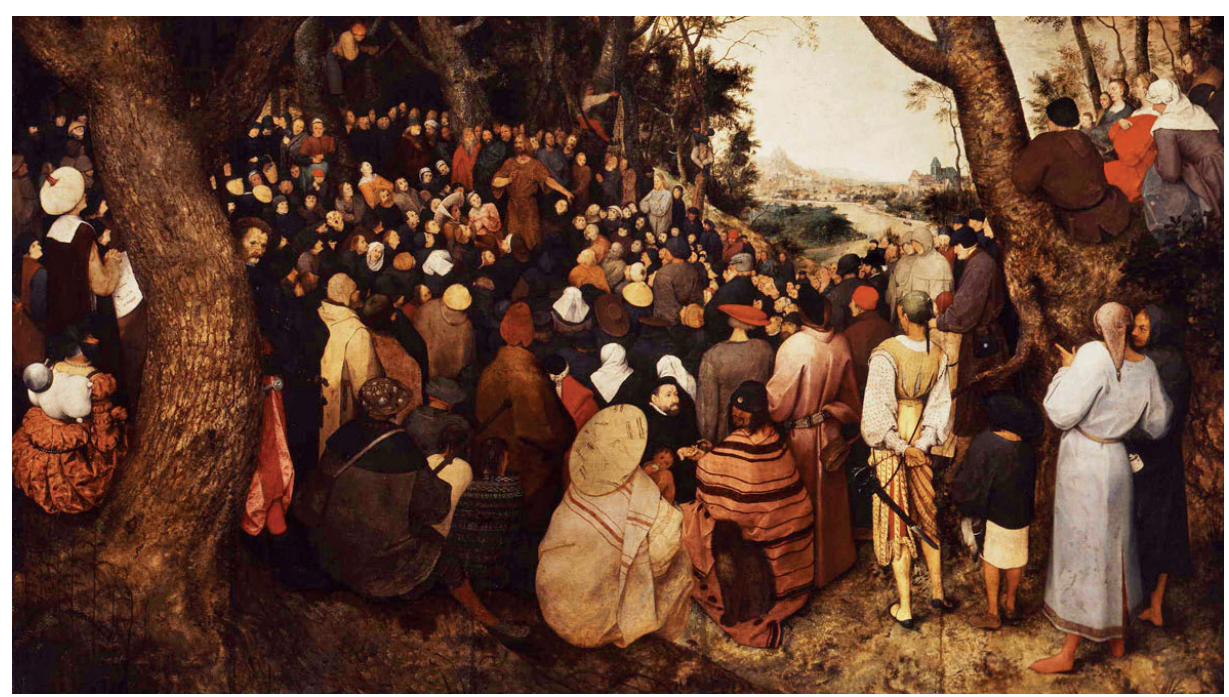

Figure 12. Pieter Bruegel the Elder - The Preaching of Saint John the Baptist (1566) Museum of Fine Arts, Budapest

a deathbed scene of the Holy Mary, which had profound Catholic connotations, showing the Virgin Mary, a figure largely marginalized in Protestant belief, was recuperated by the 'Protestant' artist Rembrandt van Rijn in a mixing process that resulted in the etching The Death of the Virgin (1639). This disquieting presence of a Catholic subject that was hardly acceptable to Dutch Protestant eyes, illustrates that Rembrandt subversively acknowledged the place of the Virgin Mary in the Catholic visual practice and the contemporary Catholic theology of his age (Barker, 2010). It also demonstrates that fundamental hybridization dynamics of cultural mobility and "the creativity of reception and the renegotiation of meaning" (Burke 2009: 107) take place in encounters.

Transculturation is not always overt and is not unidirectional either. The cultural mobility in Netherlandish art worked both ways. Netherlandish artists influenced foreign artists, but foreign artists also influenced Netherlandish artists. In the perspective of A New European Narrative for culture, it is crucially important to pay attention to the intricate and continuous cross-pollination of the diversity of cultures in Europe and to discover that the processes of interaction, although sometimes highly complex and profound, have not washed away the cultural identities.

\section{3. ‘Contact zones' where cultural goods are exchanged}

In connection with painting, identifying and analyzing the 'contact zones' where cultural goods are exchanged will direct the focus to places where intercultural contact is intensified and fertile. One such contact zone was certainly the print shop (Landau \& Parshall, 1994).

Around 1548 the Flemish painter Hieronymus Cock (1517/8-1570) came back from Italy and founded with his wife Volxcken Diercx In de Vier Winden (At the Four Winds), 


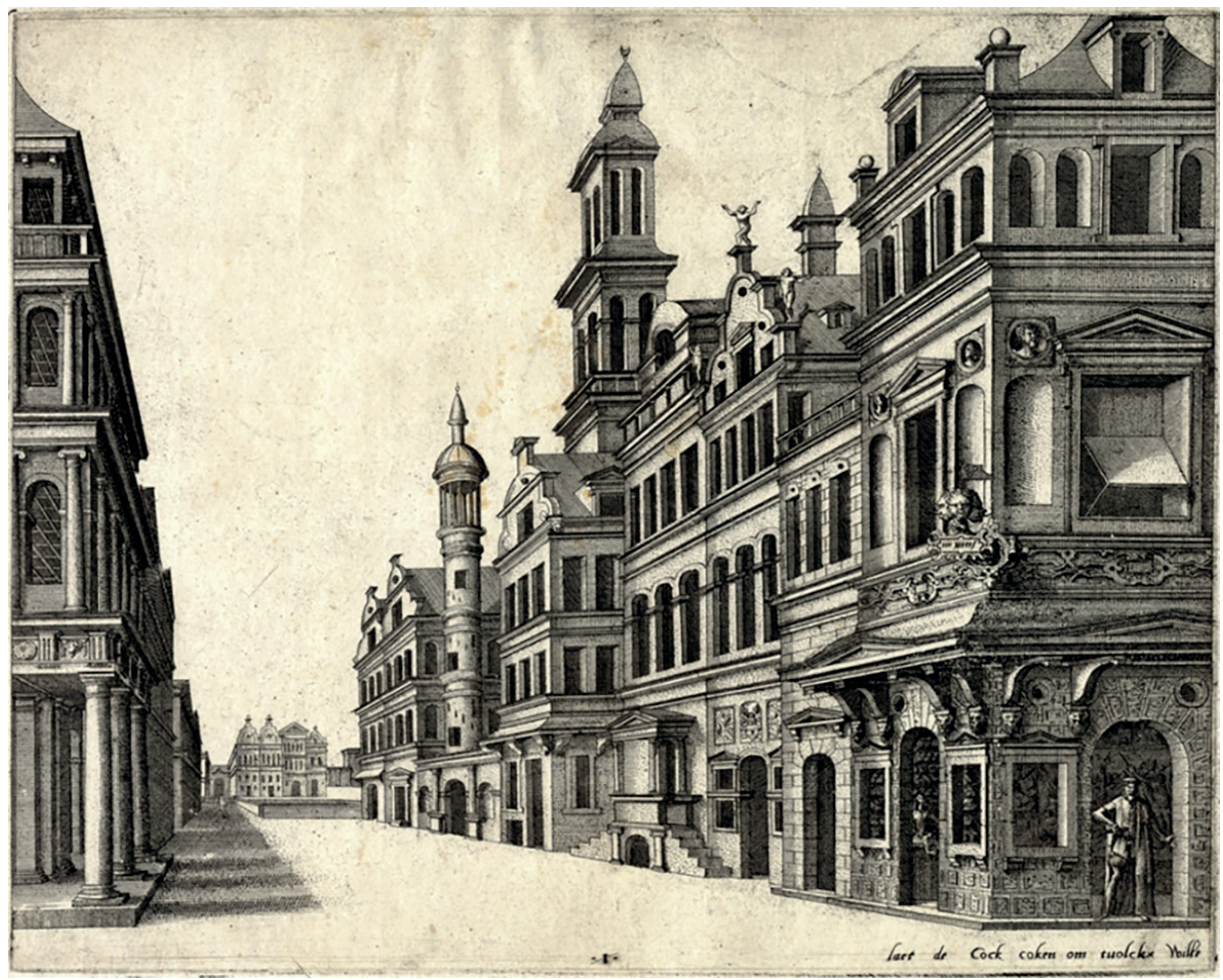

Figure 13. Print shop 'In de vier winden' - Joannes and Lucas van Doetecum after Hans Vredeman de Vries

a print shop in Antwerp, which became a meeting point for artists from the Netherlands and Italy and where humanists and art lovers from all over Europe met one another. Cock published innovative prints (by Bruegel, Giorgio Ghisi a.o.) of great renaissance masters like Raphael, Bronzino, Vasari, Floris, Lombard and Heemskerck. The flourishing print commerce of Hieronymus Cock highly contributed to the spreading of the Italianate renaissance style in Northern Europe. Appreciation for classical antique architecture, for instance, was greatly promoted by prints like the architectural fantasy by Hans Vredeman de Vries, showing us Cock's print shop in an idealized print by Joannes and Lucas van Doetecum after Hans Vredeman de Vries, Imaginair gezicht op een straat met het huis In de Vier Winden (Imaginery view on a street with the house At the Four Winds), from the series Scenographiae sive perspectivae, 1560 (Figure 13). Cock is standing in the gate of his shop and his wife is posing behind the sales counter. The text says: "let the cook (Cock), cook to the benefit of the people" ("laet de Cock coken om volcks wille"), thus punning on the name of the shop owner.

Thousands of prints from the best engravers of Europe thus found their way into the Netherlands and played a key role in the breakthrough of new artistic ideas. The Italian engraver Giorgio Ghisi, for instance, worked for Cock. He engraved, among other prints, a great School of Athens (1550) (Figure 14) after the famous School of Athens from the Stanze del Vaticano by Raphael. 


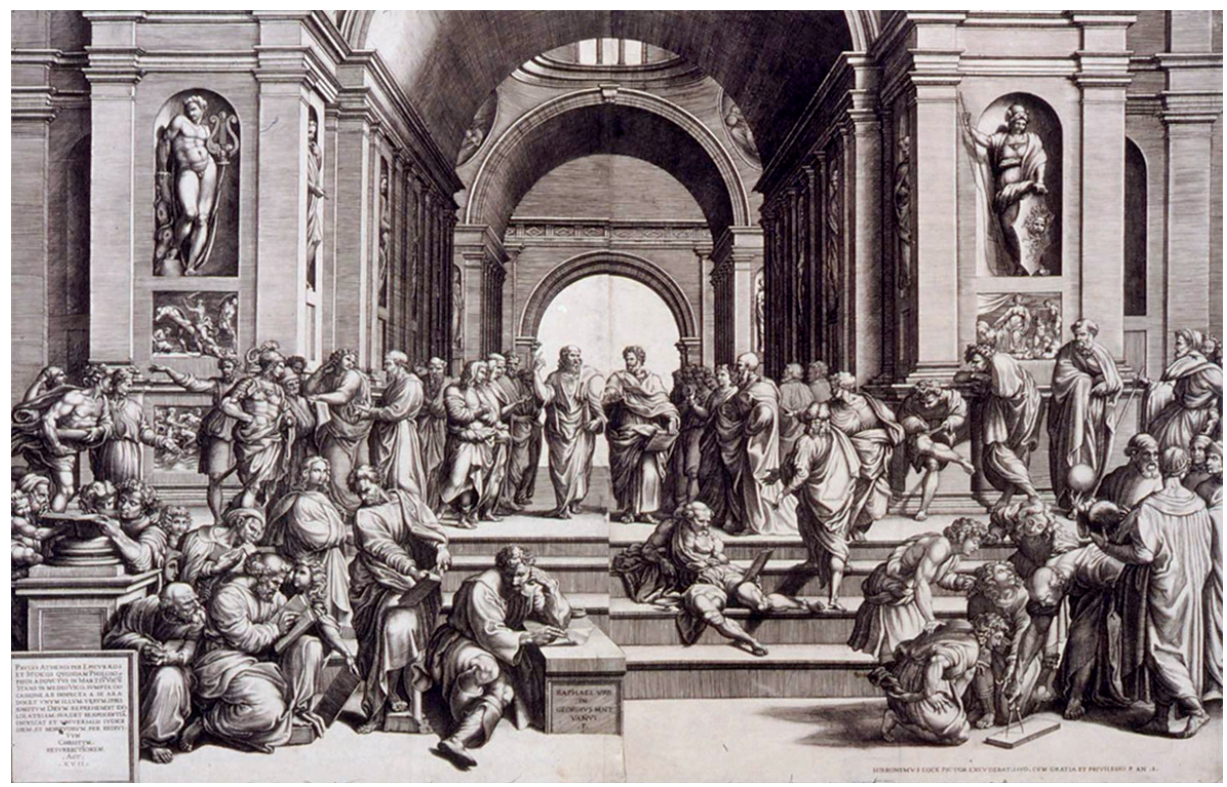

Figure 14. Giorgio Ghisi - The School of Athens, print (1550) after Raphael

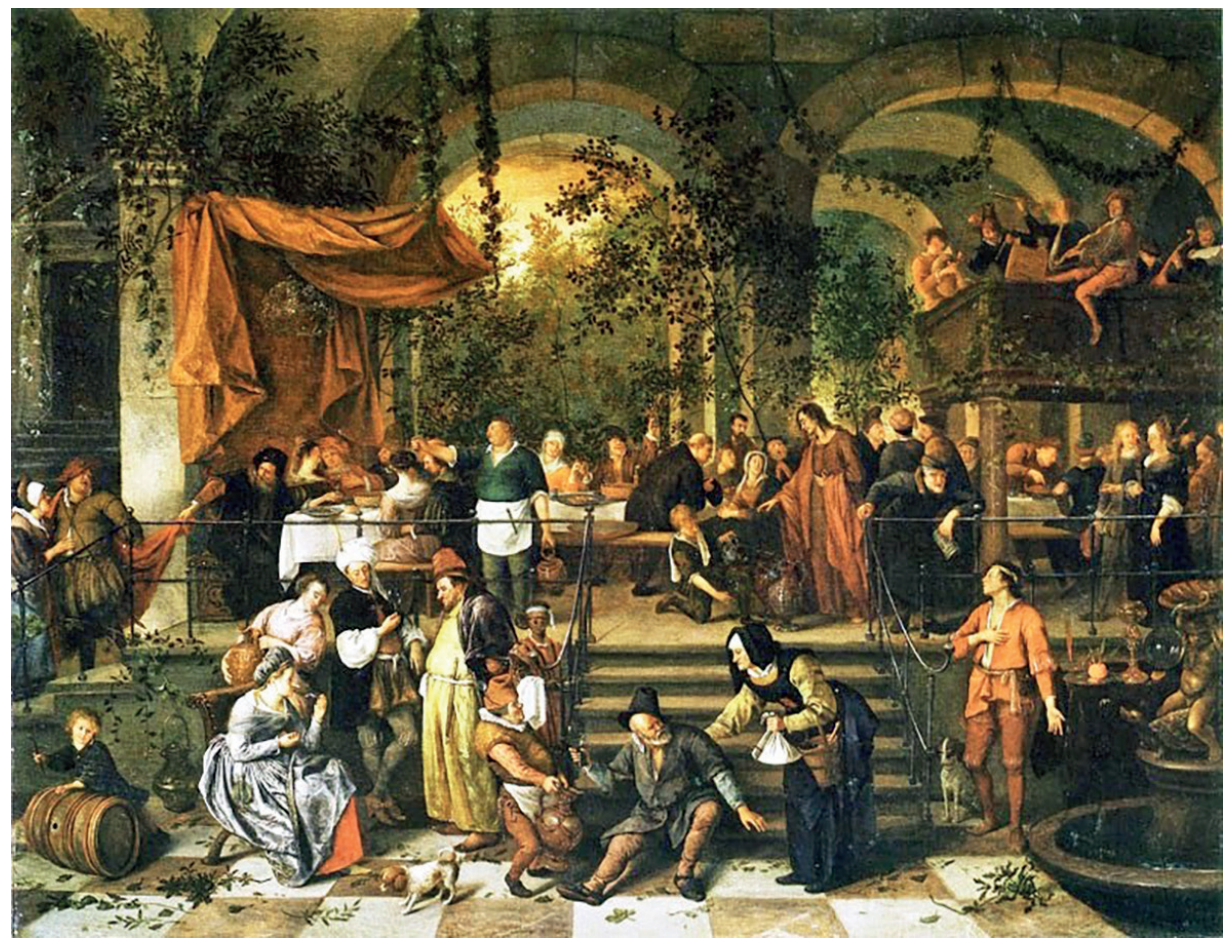

Figure 15. Jan Steen - The Wedding at Cana (ca. 1670) - National gallery of Ireland, Dublin 
This engraving clearly influenced Jan Steen's Wedding at Cana as De Groot (1952: 81) has convincingly indicated. But although the architecture, the composition and the posture of the figures (e.g. attitude of the broadly posing farmer) have been influenced by the Ghisi print, Steen transformed Raphael's solemn and dignified image it into a popular Dutch wedding scene (Figure 15).

In his composition Steen might also have been influenced by the great monumental painting of The wedding at Cana (1562-63) by Paolo Veronese as Stechow (1972: 73) suggested, a painting Steen might have been familiar with.

The contact zones were really centers of exchange, where fruitful transculturation took place, also radiating from the genuine Netherlandish art. Thus the Netherlandish work of Hieronymus Bosch or Pieter Bruegel the Elder also found its way abroad. The famous Flemish artist Pieter Bruegel the Elder worked for Hieronymus Cock's print shop and it is known that in his day he first made his name among the general public as a designer of prints. Commissioned by the owner of the Antwerp print shop, Bruegel produced more than sixty drawings which were cut in copper by the best engravers of his time. The work comprised distinctly marked Flemish work (comparable to the work of Hieronymus Bosch e.g.: Big fish eat little fish), also popular Flemish work (Skaters on the ice) or moralizing prints (Seven virtues, Seven deadly sins), as well as landscapes from his 'Grand Tour' to Italy. Cock set about making Bruegel a star artist and spreading Netherlandish influence by diffusing his prints throughout Europe.

Not only print shops were centers of cultural exchange, courts too were often highly prolific sources of cultural mobility. For Italy, I already mentioned the court of Leonello d'Este in Ferrarra, a meeting point of humanist scholarship and Italian and Netherlandish artists, but also a place where Netherlandish works of art could be admired. Testimonies of humanists of fifteenth-century courts in Italy of, among others, Naples (Summonte), Ferrara (Ciriaco d'Ancona), Venice (Marcantonio Michiel) testify not only to the presence of Netherlandish art at Italian courts but also to its influence on Italian artists and to its exceptional artistic merit. The quattrocento courts and their immediate networks were certainly major causes of cultural mobility.

The same holds true, of course, for the famous Habsburg court of Emperor Rudolf II, in Prague around 1600, whose patronage of several Netherlandish artists (among them the 'Rembrandt among the sculptors', Adriaen de Vries, but also Carel van Mander) lay at the basis of a very international 'Stylish style', a European mannerism that soon became very popular. Especially the virtuosic works made by the Netherlandish court painter Bartolomeus Spranger (1546-1611) helped to spread Mannerism from the court of Rudolf II all over Europe. Rudolf's preference for allegorical and mythological themes with an erotic flavor can be noticed in Spranger's Angelica and Medor for instance, which shows the typical mannerist complicated and contorted poses only attained by well-trained gymnasts. The elegant and undulating lines of their sophisticated poses were soon imitated in the rest of Europe.

Apart from print shops and courts, from the sixteenth century on, picture galleries ('Picture Galleries', like The Picture Gallery of Cornelis van der Geest, 1628 by Willem van Haecht) with collections of foreign and local paintings became international meeting places where agents prospected with 'connoisseurs' and functioned as 'mobilizers' between commanders' expectations and artists' competences. Analyzing the responses to 
these influential contact zones reveals patterns of accommodation, compromise, rejection and opinionated stubbornness related to the tension between cultural persistence and change.

\section{Tension between individual agency and structural constraint causing cultural mobility}

Accounting for the tension between individual agency and structural constraint, could easily be done by investigating the changing social position of the artists in response to changing circumstances in society. There was indeed a striking artistic mobility to be noticed in response to the change in social position of the painters in the course of the $15^{\text {th }}$ to the $17^{\text {th }}$ century.

In the fifteenth century, painters like Jan van Eyck or Rogier van der Weyden largely responded to the contemporary taste of the court and the church, though at the same time exhibiting their individual talents (Beheydt 2015). Van Eyck primarily satisfied the Burgundian need for display of wealth and luxury, whereas Van der Weyden responded to the societal urge for devout drama. Thus, Van Eyck, when asked to portrait the Bur-

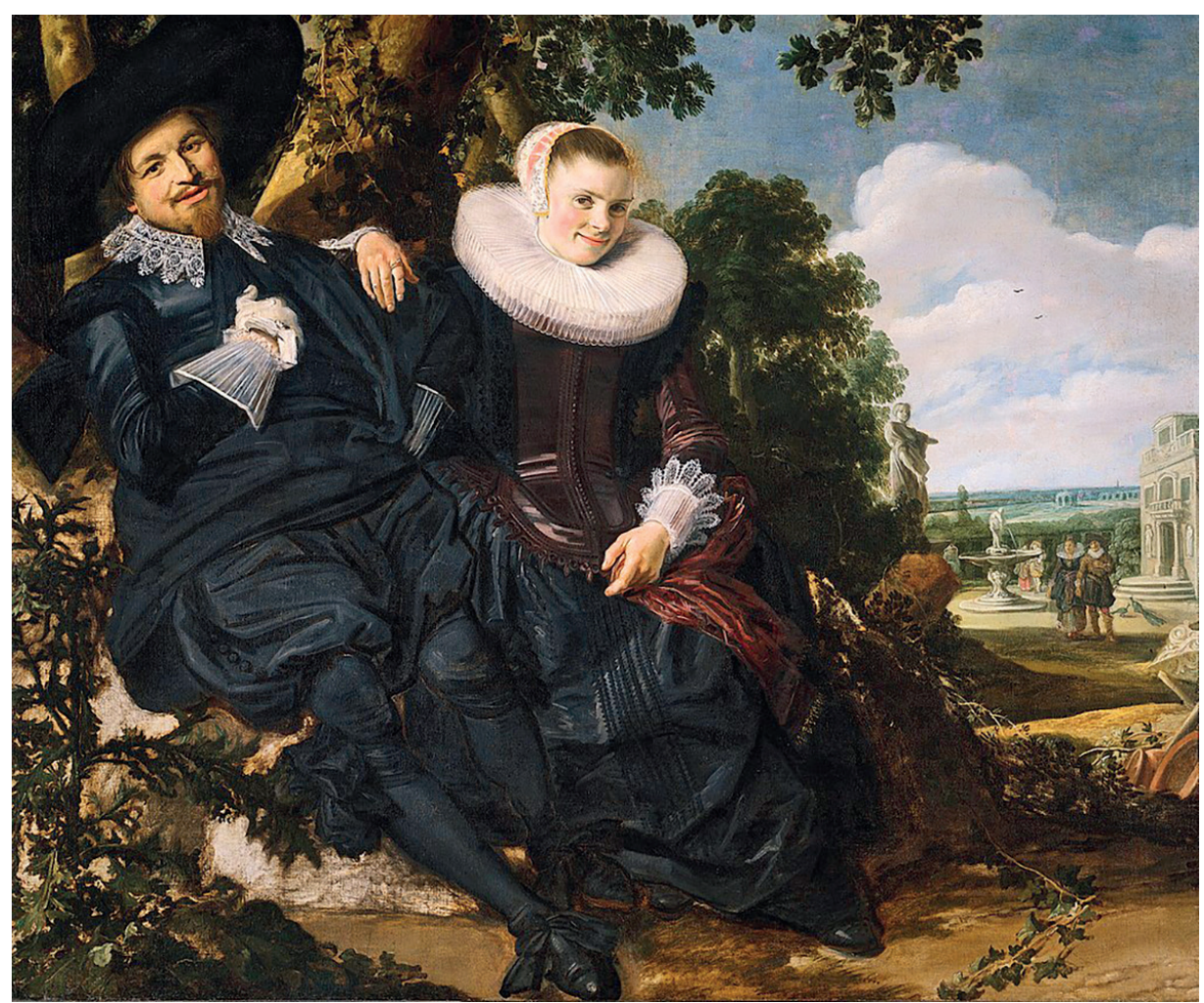

Figure 16. Frans Hals - Marriage Portrait of Isaac Massa and Beatrix van der Laen (1622) Rijksmuseum, Amsterdam 
gundian chancellor Rolin, depicts the wealthy chancellor kneeling before the Virgin and Child in all his splendor. The ostentatious figure of the donor, dressed in gold brocade and furs, like a prince, betrays his desire to be seen as a high-ranking court dignitary. The picture presents us with a sacra conversazione, a "holy conversation" between the Holy Mary and the mighty donor. Van Eyck helped to disseminate this genre, which was to become very popular in Italy.

In the $17^{\text {th }}$ century, with the rise of the modern merchant society in the Dutch Republic, artists started to work for a market and responded more and more to the bourgeois taste of their public, painting intimate bourgeois interiors, decorative still-lifes, family portraits and local landscapes. The new society thus caused a radical artistic mobility, changing court taste into bourgeois taste. A fine example of the new bourgeois taste that caught painting would be the portrait of Isaac Massa and his Wife Beatrix van der Laen (Figure 16), the extremely rich Amsterdam grain trader, painted by Frans Hals in 1621. This merchant is conspicuously portrayed as a smartly dressed self-confident successful business man in his silk costume with his wife Beatrix van der Laen at his side, showing off his wealth in a very bourgeois love garden.

\section{The sensation of rootedness}

Finally, analyzing the sensation of rootedness that codetermines cultural mobility, can be undertaken by showing how Netherlandish painting, despite foreign influences has developed a specific cultural identity that is linked to a particular time and place (Beheydt 2002; Brown 2002). For a European population of a great diversity it must be a relevant experience to be shown in how far Flemish and Dutch art were heir to their own tradition and, yet, have been constantly reshaping and recreating their cultural identity in confrontation with disruptive forces. Investigating the sensation of rootedness is particularly important to make us aware of the paradoxical character of cultural identity in an era of super-diversity. Studying cultures as a process of mobility across times and places, while at the same time recognizing the ways in which these cultures have safeguarded their identity and continuity, should prove that intercultural encounters are not a threat to cultural identities in Europe.

It can convincingly be shown how in the early modern times, notwithstanding the influence of the mythological and biblical inspiration and the introduction of foreign influences, artists like Bruegel and Rubens remained genuinely Flemish. The sensation of rootedness with Bruegel's paintings, for instance, is undeniable. It suffices to compare a popular Marcantonio Raimondi print of the biblical theme of The massacre of the innocents (Figure 17) to the Mannerist treatment of the same theme by the Dutch painter Cornelis van Haarlem (1591) (Figure 18) who was greatly influenced by the Italian renaissance, and then to look at the elaboration of the same theme by Pieter Bruegel the Elder (ca. 1565-1567) (Figure 19), who sets the biblical event in a Flemish snowy village, alluding covertly and subversively to the Spanish domination and suppression in the Netherlands by staging a typical Spanish army in the background of the brutal massacre. The Netherlandish cultural rootedness of Bruegel has obviously not been washed away by encounters with foreign cultures. 


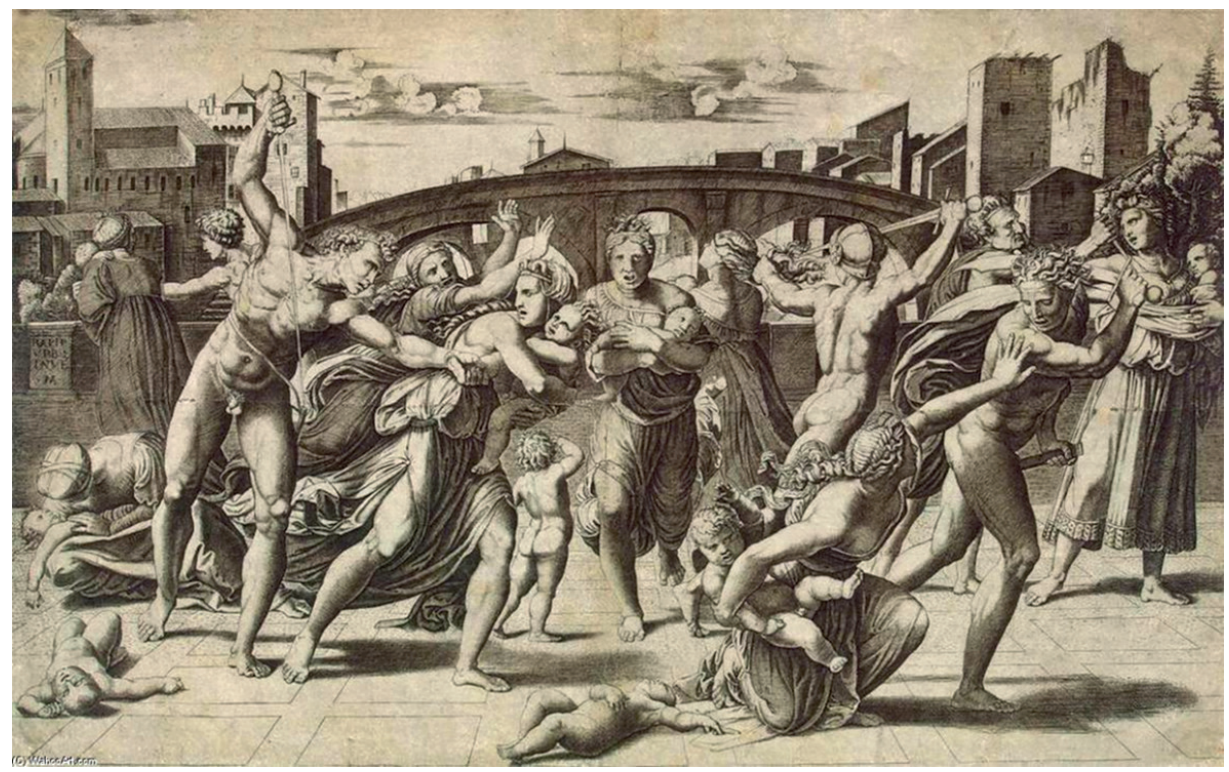

Figure 17. Massacre of the innocents in Bethlehem (Antonio Raimondi after Raphaël)

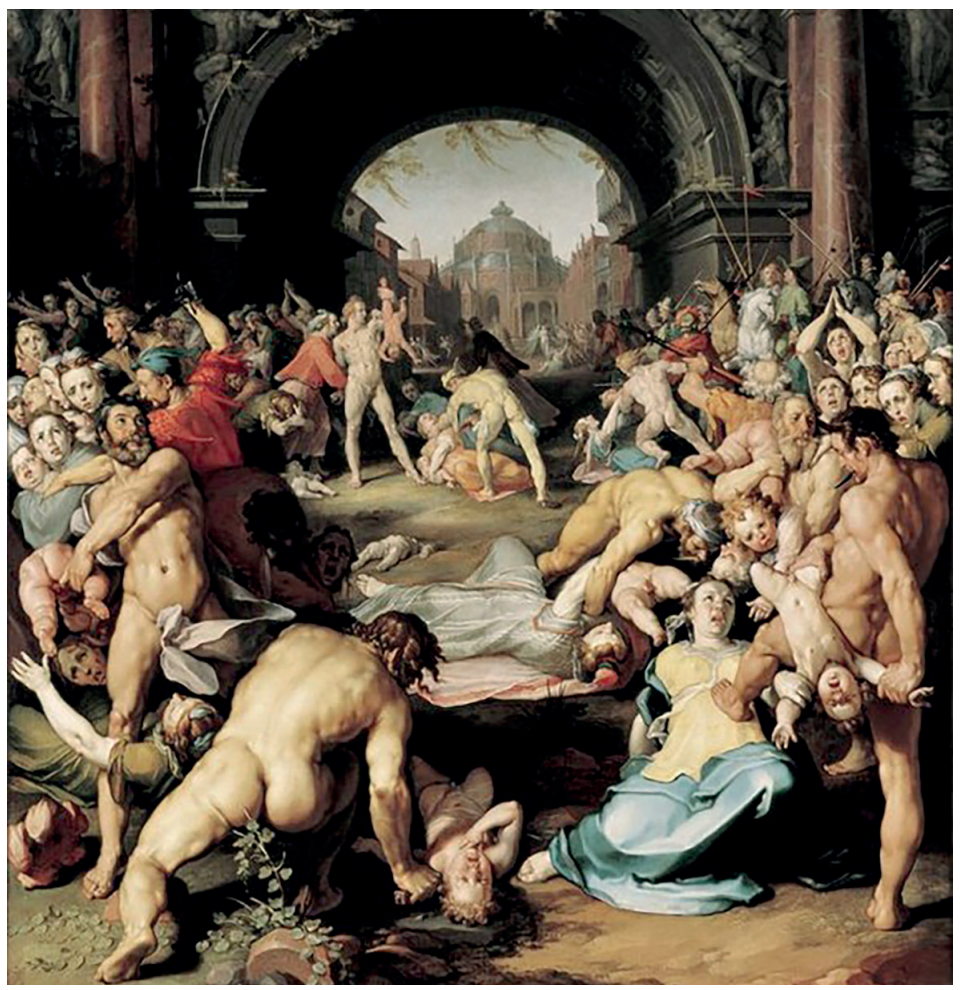

Figure 18. Cornelis van Haarlem - Massacre of the innocents in Bethlehem (1591) - Frans Hals Museum 


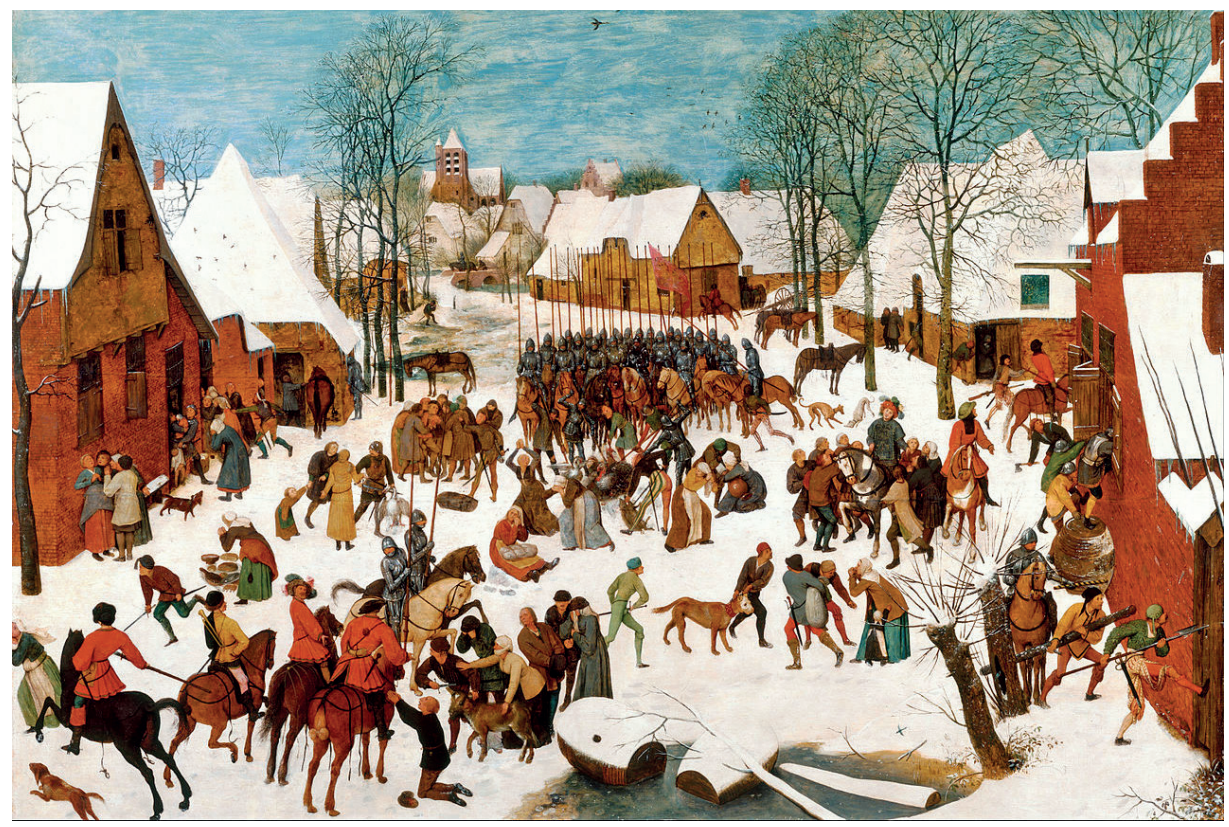

Figure 19. Pieter Bruegel the Elder - Massacre of the innocents in Bethlehem (ca. 1565-67) Royal Collection, Windsor Castle

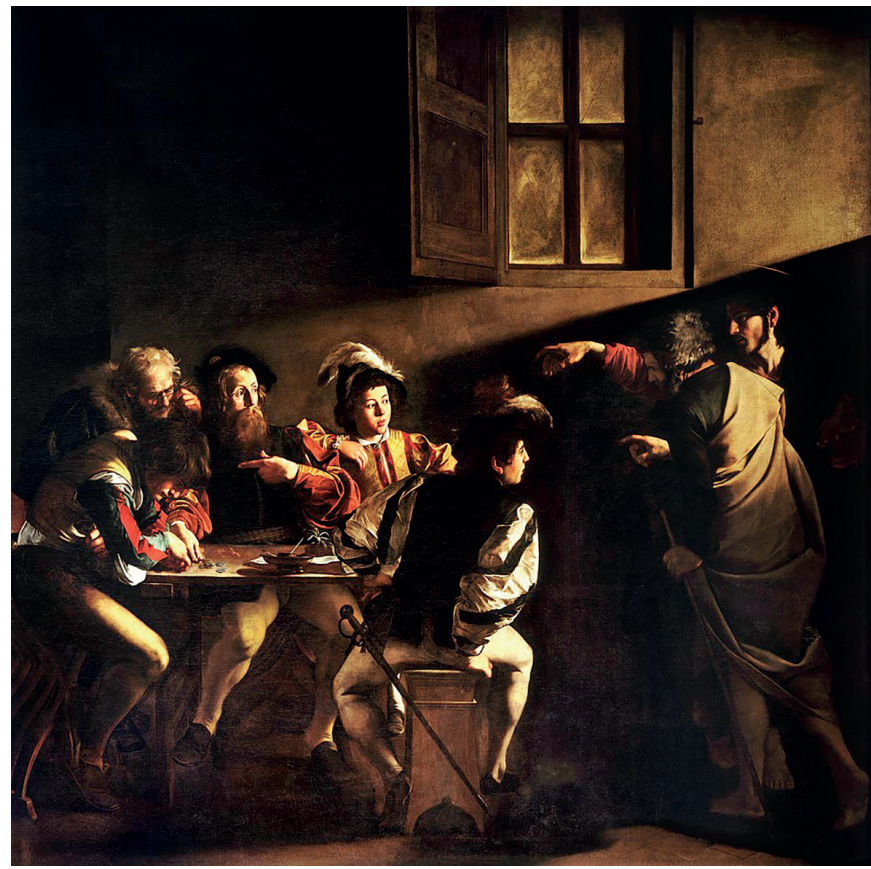

Figure 20. Michelangelo Merisi da Caravaggio - The Calling of Saint Matthew (1599-1600) San Luigi dei Francesi, Rome 


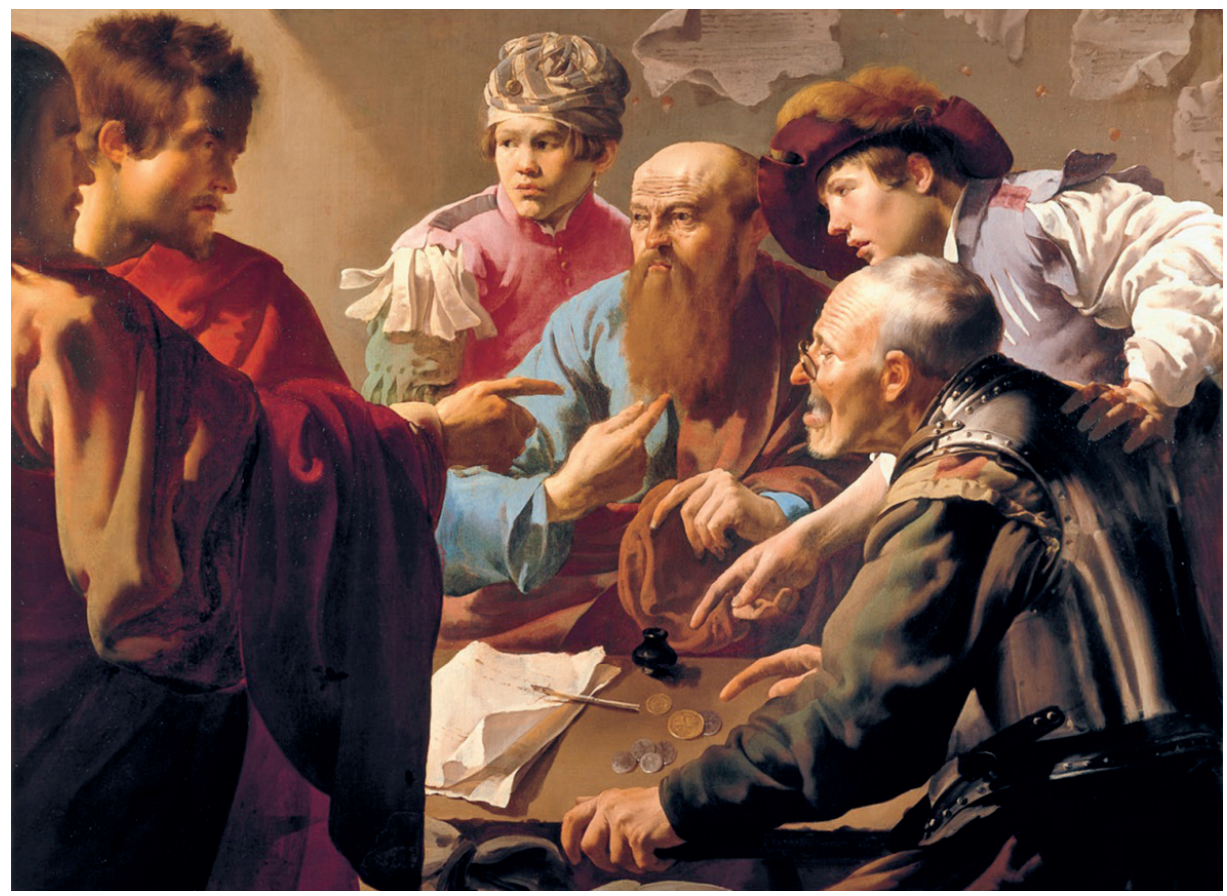

Figure 21. Hendrick Terbrugghen - The Calling of Saint Matthew (1621) - Centraal Museum, Utrecht

Not only in Flanders, in the Dutch Republic too, the foreign influences were absorbed and merged into the native tradition. In that respect, I wanted to come back to the already mentioned Utrecht School of the seventeenth century, which brought caravaggesque influences tot the Dutch Republic through the work of Honthorst, Baburen en Terbrugghen. Just to show how the Netherlandish character is preserved in otherwise caravaggesque works, let me compare the same biblical theme in a painting by Michelangelo Merisi da Caravaggio (1599-1600) (Figure 20) and in one by Hendrick Terbrugghen (Figure 21). Surely, Terbrugghen's Calling of Saint Matthew (1621) is deeply influenced by Caravaggio's example in its strong dramatic composition and chiaroscuro, but the treatment of the facial physiognomy shows at the same time that Terbrugghen is deeply rooted in the Netherlandish tradition. The verisimilitude of the bewilderment in the face of the tax collector and of the miserly greediness in the old man remind us of types popularized by early $16^{\text {th }}$ century Flemish artists. And the light in the painting, in line with the older Netherlandish tradition, is less hard and more atmospheric than with Caravaggio.

\section{Conclusion}

I hope the present article has helped to understand the true nature of cultural identity and the importance therein of cultural mobility. I have tried to show, how mutual influences have created a European art that, though consisting of artistically recognizable 
identities, develops in dynamic interaction. My purpose has been to combine a deepening insight into the cultural mobility in European art with the comforting and reassuring recognition of its fertile diversity. If I have underpinned my ideas concerning a 'New Art Historic Narrative' about the artistic identity of Europe, referring mainly to Netherlandish and Italian art, I am convinced that one could readily extend and extrapolate my model of art history to, for instance, Czech art. It can easily be shown that a similar approach might strengthen the confidence in the Czech cultural identity while at the same time revealing the international importance of the Czech contribution to European art. Would it not be marvelous if Europe could learn to appreciate Alfons Mucha (1860-1939) not merely as the greatest decorative artist in the Europe of the fin-de-siècle and as the great innovator of Art nouveau in Paris, but also as a deeply conscious Czech artist, who created that beautiful national Slovanská epopej (The Slav Epic) as an evocation of Czech cultural identity in the European fin-de-siècle (Polakovicová, 2007)?

\section{BIBLIOGRAPHY}

AINSWORTH, MARYAN W. (ed.) (2010). Man, Myth, and Sensual Pleasures: Jan Gossart's Renaissance: The Complete Works. New York: Yale University Press.

BARKER, MARY CHRISTINE (2010). 'Transcending tradition: Rembrandt's Death of a Virgin 1639: A Re-Vision.' Dutch Crossing 34:2, pp. 138-161.

BEHEYDT, LUDO (2002). Eén en toch apart. Kunst en cultuur van de Nederlanden. Leuven: Davidsfonds.

BEHEYDT, LUDO (2015). 'Een semiotische interpretatie van het werk van de Vlaamse Primitieven tegen de achtergrond van de Bourgondische cultuur'. In: Jana Engelbrechtová (ed.): De Nederlandstalige cultuur internationaal. Centraal-Europa en de Lage Landen. Olomouc: Universita Palackého v Olomouci, pp. 3-37.

BROWN, CHRISTOPHER (2002). The Dutchness of Dutch Art. Amsterdam: Amsterdams Centrum voor de Studie van de Gouden Eeuw, Universiteit van Amsterdam.

BURKE, PETER (2009). Cultural hybridity. Cambridge: Polity Press.

DACOS, NICOLE (1995). 'Om te zien en te leren'. In: H. Devisscher (ed.) Fiamminghi a Roma 1508-1608. Brussel PSK: Snoeck-Ducaju \& Zoon, pp. 14-31.

GREENBLATT, STEPHEN (ed.) (2010). Cultural Mobility: A Manifesto. New York: Cambridge University Press.

GROOT, CORNELIS W. DE (1952). Jan Steen: beeld en woord. Utrecht: Dekker \& Van de Vegt.

HOOGEWERFF, G. J. (1947). De Noord-Nederlandsche schilderkunst. 's-Gravenhage: Martinus Nijhoff.

JUDSON, JAY R. J. (1959). Gerrit van Honthorst: A Discussion of his Position in Dutch Art. Reprinted Springer (1961).

KEMPERDICK, STEPHAN (1999). Rogier van der Weyden. Köln: Konemann.

LANDAU, DAVID \& PETER W. PARSHALL (1994). The Renaissance print: 1470-1550. Yale University Press.

MANDER, KAREL VAN (1604). Schilder-boeck The Lives of the Illustrious Netherlandish and German Painters. Translated and edited by Hessel Miedema. Doornspijk: DAVACO (1994).

NUTTALL, PAULA (2004). From Flanders to Florence. The Impact of Netherlandish Painting, 1400-1500. New Haven and London: Yale University Press.

POLAKOVIČOVÁ, EVA (2007). Alfons Mucha en het Slavische Epos. Kunst als expressie van de nationale en culturele identiteit. Masterscriptie Universiteit Leiden: Leiden.

STECHOW, WOLFGANG (1972). 'Jan Steen's Representations of the Marriage in Cana'. Nederlands Kunsthistorisch Jaarboek 23 (1), pp. 73-83. 


\title{
EVROPSKÝ VLIV NIZOZEMSKÉHO A VLÁMSKÉHO UMĚNÍ. \\ KULTURNII MOBILITA
}

Budoucnost evropských interdisciplinárních studií o kultuře spočíá v uznání dynamiky evropské kultury. Chceme-li, aby se evropští občané identifikovali s Evropou, musíme jim nabídnout evropskou kulturu, s níž se mohou ztotožnit. Taková možnost ztotožnění se nenachází v národních dějinách nebo v izolovaně studované národní kultuře. Není navíc ani součástí evropské historie ani kultury. Evropa nemá společnou kulturní identitu, nemá sdílenou sít významu. Řešení dilematu je v pojetí evropské kultury jako výsledku nepřetržitého vzájemného ovlivňování. Takový názor je zde představen na př́ikladu př́stupu k umění, který se zaměřuje na vlámské a nizozemské umění jako na místo setkávání kulturních vlivů.

\author{
Ludo Beheydt \\ Université Catholique de Louvain \\ E-mail: Ludo.Beheydt@skynet.be
}

